\title{
The Aporia of Future Directed Beliefs
}

\section{Daniel Rönnedal ${ }^{1}$}

Received: 5 December 2019 / Accepted: 1 September 2020/ Published online: 12 September 2020

(C) The Author(s) 2020

\begin{abstract}
This paper discusses a new aporia, the aporia of future directed beliefs. This aporia contains three propositions: (1) It is possible that there is someone who is infallible that believes something about the future that is not historically settled, (2) it is necessary that someone is infallible if and only if it is necessary that everything she believes is true, and (3) it is necessary that all our beliefs are historically settled. Every claim in this set is intuitively plausible, and there are interesting arguments for or against each of them. Nevertheless, $\{(1),(2),(3)\}$ entails a contradiction. Consequently, at least one of the sentences in this set must be false. I consider some possible solutions to the problem and discuss some arguments for and against these solutions. Five solutions, in particular, stand out. Three solutions reject (1), one solution rejects (2), and one solution rejects (3). No solution is without problems, and it is not obvious which one we should choose. Yet, we have to give up at least one sentence in $\{(1),(2),(3)\}$. This is the nature of an aporia.
\end{abstract}

Keywords Aporia $\cdot$ Future directed beliefs $\cdot$ Infallibility $\cdot$ Historical necessity $\cdot$ The open future

\section{Introduction}

Consider the following set of propositions:

(1) It is possible that there is someone who is infallible that believes something about the future that is not historically settled.

(2) It is necessary that someone is infallible if and only if it is necessary that everything she believes is true.

Daniel Rönnedal

daniel.ronnedal@philosophy.su.se

1 Stockholm University, Stockholm, Sweden 
(3) It is necessary that all our beliefs are historically settled (i.e., facts about what someone believes are historically settled). In other words, it is necessary that if an individual $\mathrm{x}$ believes that $\mathrm{A}$, then it is historically settled that $\mathrm{x}$ believes that $\mathrm{A}$.

All these propositions are intuitively plausible, but together they entail a contradiction. This is the aporia of future directed beliefs. It is called the "aporia of future directed beliefs" because (1) talks about beliefs about the future. This puzzle should be interesting to anyone who philosophizes about the concepts of belief, infallibility, historical necessity, the open future, and similar concepts and about the relationships between such notions. ${ }^{1}$

To justify the claim that $\{(1),(2),(3)\}$ is inconsistent but that the sentences in this set are intuitively plausible, we shall first say a few more words about (1)-(3) and express these propositions in symbols. " $\mathrm{A}$ " says that it is possible that $\mathrm{A}$; " $\mathrm{A}$ " says that it is necessary that $A$; " $\square A$ " says that it is historically settled that $A$; " $\diamond A$ " says that it is historically possible (open) that A; "BcA" says that c believes that A; "FA" says that it will some time in the future be the case that A; and "Ic" says that c is infallible ("I" is a predicate). "BcA" represents a future directed belief if $\mathrm{A}$ is about the future. Let $\mathrm{p}$ be an atomic sentence. Then BcFp is a future directed belief. All other symbols are interpreted in a standard way. (1)-(3) can now be formalized as follows:

(1) $\exists \mathrm{x}(\mathrm{Ix} \wedge \exists \mathrm{A}(\mathrm{BxFA} \wedge \neg \square \mathrm{FA}))$. It is possible that there is an individual $\mathrm{x}$ such that $\mathrm{x}$ is infallible and there is a proposition A such that $\mathrm{x}$ believes that it will be the case that A (some time in the future) and it is not historically settled that it will be the case that A (some time in the future).

Note that (1) only says that it is possible that there is someone who is infallible that believes something about the future that is not historically settled. This proposition does not entail that there (actually) is anyone who is infallible. The first quantifier varies over individuals and the second over propositions or sentences. " $\exists \mathrm{A}(\mathrm{BxFA} \wedge \neg \square \mathrm{FA})$ " says that there is a proposition A such that $\mathrm{x}$ believes that it will some time in the future be the case that A and it is not historically settled that it will some time in the future be the case that A. Some things about the future are historically settled, for example, that it will or that it will not rain (here) tomorrow. But some things seem to be historically open, for example, that Germany will win the next World Cup in football. It is now historically possible that Germany will win the next World Cup and it is historically possible that Germany will not win the next World Cup (or so it seems). If $\mathrm{x}$ believes that Germany will win the next World Cup in football and it is not historically settled

\footnotetext{
${ }^{1}$ There are some similarities between the aporia introduced in this paper and the so-called problem of (divine) foreknowledge and freedom (for more on this problem, see, e.g., Craig (1988), Hasker (2011) and Zagzebski (2005)). However, there are also important differences. First, I am not concerned with any specific religious doctrines in this paper, even though the discussion can have various interesting consequences for different debates in the philosophy of religion. Second, the aporia does not include a proposition about the possible existence of an omniscient being. If someone is omniscient (and consistent), she is also infallible. But someone can be infallible without being omniscient. The proposition that it is possible that there is someone who is infallible is therefore weaker than the proposition that it is possible that there is someone who is omniscient. Third, the aporia does not speak about (human) freedom but about the open future. According to some theories, humans can have a free will even if the future is not open. Fourth, the details of the arguments in this paper are quite different from the details of the arguments in the literature on the problem of (divine) foreknowledge and freedom. Therefore, the aporia of future directed beliefs clearly is a new aporia, even though it is in some respects similar to the problem of (divine) foreknowledge and freedom.
} 
that Germany will win the next World Cup in football, then " $\exists \mathrm{A}(\mathrm{BxFA} \wedge \neg \square \mathrm{FA})$ " is true. Intuitively, " $\exists \mathrm{x}(\mathrm{Ix} \wedge \exists \mathrm{A}(\mathrm{BxFA} \wedge \neg \square \mathrm{FA})$ " just says that it is possible that there is some proposition of this kind that someone who is infallible believes. This certainly appears to be possible.

(2) $\boldsymbol{\square} \forall \mathrm{x}(\mathrm{Ix} \leftrightarrow \boldsymbol{\mathrm { m }} \mathrm{A}(\mathrm{BxA} \rightarrow \mathrm{A}))$. It is necessary that for every (individual) $\mathrm{x}: \mathrm{x}$ is infallible if and only if it is necessary that for every (proposition) $\mathrm{A}$, if $\mathrm{x}$ believes that $\mathrm{A}$ then A.

(2) is simply a definition of what we mean by "infallible." Obviously, (2) in itself does not entail that there is anyone who is infallible. The first quantifier in (2) varies over individuals and the second over propositions or sentences.

(3) $\square \forall \mathrm{x} \forall \mathrm{A}(\mathrm{BxA} \rightarrow \square \mathrm{BxA})$. It is necessary that for every (individual) $\mathrm{x}$ and for every (proposition) $\mathrm{A}$, if $\mathrm{x}$ believes that $\mathrm{A}$, then it is historically settled that $\mathrm{x}$ believes that $\mathrm{A}$.

(3) is intuitively plausible. As soon as someone believes something, it seems to be historically settled that she believes this thing. If this is not the case, then it is possible that there is someone who believes something even though it is not historically settled that she believes it. But this is intuitively implausible. Note that " $\square \mathrm{BxA}$ " in (3) says that it is historically settled that $\mathrm{x}$ believes that $\mathrm{A}$, not that it is (absolutely) necessary that $\mathrm{x}$ believes that A. $\forall \forall \mathrm{x} \forall \mathrm{A}(\mathrm{BxA} \rightarrow \mathbf{B x A})$ does not hold. It is possible that there is someone who believes that A even though it is not (absolutely) necessary that she believes that A. Again, note that the first quantifier in (3) varies over individuals and the second over propositions or sentences.

\subsection{Logical Symbols and Assumptions}

Before we establish that $\{(1),(2),(3)\}$ entails a contradiction, we will say a few more words about the logical symbols and assumptions that are used in this paper. "a" and " function as "absolute" S5 operators in this paper, and " $\square$ " and " $\diamond "$ function as "relative" S5 operators. $\mathrm{A}$ is true in a possible world at a moment in time if and only if $\mathrm{A}$ is true in every possible world at every moment in time. $\mathrm{A}$ is true in a possible world at a moment in time if and only if $\mathrm{A}$ is true in some possible world at some moment in time. Since "घ" and "\$" stand for absolute necessity and possibility (respectively), it is obvious that they are $\mathrm{S} 5$ operators. $\square \mathrm{A}$ is true in a possible world $\mathrm{w}$ at a moment in time $\mathrm{t}$ if and only if $\mathrm{A}$ is true in every possible world that is still historically accessible from $\mathrm{w}$ at $\mathrm{t} . \diamond \mathrm{A}$ is true in a possible world $\mathrm{w}$ at a moment in time $\mathrm{t}$ if and only if $\mathrm{A}$ is true in some possible world that is still historically accessible from $\mathrm{w}$ at $\mathrm{t}$. In other words, we can say that $\mathrm{w}^{\prime}$ is historically accessible from $\mathrm{w}$ at $\mathrm{t}$ if and only if $\mathrm{w}^{\prime}$ is still possible given the history of $\mathrm{w}$ and the laws of nature that hold in $w$ (in a tree-like structure, $w$ and $w^{\prime}$ have not yet branched off at $t$ ). Given this interpretation, the historic accessibility relation is an equivalence relation (i.e., it is reflexive, symmetric, and transitive at every moment in time). Hence, it follows that " $\square$ " and " $\diamond "$ function as "relative" S5 operators. $\mathrm{A}$ is stronger than $\square \mathrm{A}$ and $\diamond \mathrm{A}$ is stronger than $\diamond \mathrm{A}$. $\square \mathrm{A}$ entails $\square \mathrm{A}$ and $\diamond \mathrm{A}$ entails $\checkmark \mathrm{A}$. However, the converse does not hold. $\square \mathrm{A}$ does not entail $\square \mathrm{A}$ and $\bullet \mathrm{A}$ does not entail $\diamond \mathrm{A}$. Obviously, $\square \mathrm{A}$ entails $\square \square \mathrm{A}$ and $\diamond \mathrm{A}$ entails $\square \diamond \mathrm{A}$, but $\square \mathrm{A}$ does not entail $\square \mathrm{A}$ and $\diamond \mathrm{A}$ does not entail $\square \diamond \mathrm{A}$. Note that the logical system that is used in this paper is consistent both with the existence and the non-existence 
of contingent propositions of the following kind: $\diamond \mathrm{A} \wedge \neg \mathrm{A}$ and $\diamond \mathrm{A} \wedge \diamond \neg \mathrm{A} .^{2} \mathrm{BcA}$ is true in $\mathrm{w}$ at $\mathrm{t}$ if and only if $\mathrm{A}$ is true in all possible worlds that are doxastically accessible from $\mathrm{w}$ at $\mathrm{t}$ for the individual $\mathrm{c} .^{3}$ The truth conditions for the other formulas are standard.

\subsection{The Inconsistency Argument}

We are now in a position to show that $\{(1),(2),(3)\}$ entails a contradiction. We assume that all sentences in $\{(1),(2),(3)\}$ are true in some possible world $\mathrm{w}_{0}$ at some moment in time $t_{0}$ and derive a contradiction. In the derivation below, " $\bullet \mathrm{E}, "$ " $\exists \mathrm{E}, "$ " $\wedge \mathrm{E}, "$ " $\neg \mathrm{E}$,"

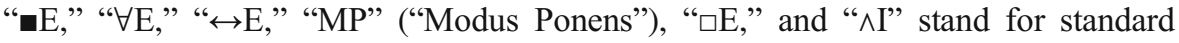
derivation rules in propositional logic, predicate logic, and modal logic. "E" is an abbreviation of "elimination" and "I" of "introduction." So " $\wedge E$ " stands for conjunction elimination and " $\wedge \mathrm{I}$ " for conjunction introduction, etc. " $\mathrm{w}_{2} \equiv \mathrm{t}_{1} \mathrm{w}_{1}$ " is an abbreviation of "the possible world $\mathrm{w}_{2}$ is historically accessible from the possible world $\mathrm{w}_{1}$ at the time $\mathrm{t}_{1}$." Intuitively, " $\mathrm{A}, \mathrm{w}_{0} \mathrm{t}_{0}$ " says that $\mathrm{A}$ is true in the possible world $\mathrm{w}_{0}$ at the time $\mathrm{t}_{0}$, etc. Here is our proof:

(1) $\triangleleft \mathrm{x}(\mathrm{Ix} \wedge \exists \mathrm{A}(\mathrm{BxFA} \wedge \neg \square \mathrm{FA})), \mathrm{w}_{0} \mathrm{t}_{0}[$ Assumption]

(2) $\quad \forall \mathrm{x}(\mathrm{Ix} \leftrightarrow \boldsymbol{\square} \forall \mathrm{A}(\mathrm{BxA} \rightarrow \mathrm{A})), \mathrm{w}_{0} \mathrm{t}_{0}[$ Assumption]

(3) $\quad \forall \mathrm{x} \forall \mathrm{A}(\mathrm{BxA} \rightarrow \square \mathrm{BxA}), \mathrm{w}_{0} \mathrm{t}_{0}$ [Assumption]

(4) $\exists \mathrm{x}(\mathrm{Ix} \wedge \exists \mathrm{A}(\mathrm{BxFA} \wedge \neg \square \mathrm{FA})), \mathrm{w}_{1} \mathrm{t}_{1}[1, \diamond \mathrm{E}]$

(5) $\operatorname{Ic} \wedge \exists \mathrm{A}(\mathrm{BcFA} \wedge \neg \square \mathrm{FA}), \mathrm{w}_{1} \mathrm{t}_{1}[4, \exists \mathrm{E}]$

(6) $\mathrm{Ic}, \mathrm{w}_{1} \mathrm{t}_{1}[5, \wedge \mathrm{E}]$

(7) $\exists \mathrm{A}(\mathrm{BcFA} \wedge \neg \square \mathrm{FA}), \mathrm{w}_{1} \mathrm{t}_{1}[5, \wedge \mathrm{E}]$

(8) $\mathrm{BcFX} \wedge \neg \square \mathrm{FX}, \mathrm{w}_{1} \mathrm{t}_{1}[7, \exists \mathrm{E}]$

(9) $\mathrm{BcFX}, \mathrm{w}_{1} \mathrm{t}_{1}[8, \wedge \mathrm{E}]$

(10) $\neg \square \mathrm{FX}, \mathrm{w}_{1} \mathrm{t}_{1}[8, \wedge \mathrm{E}]$

(11) $\mathrm{w}_{2} \equiv \mathrm{t}_{1} \mathrm{w}_{1}[10, \neg \square \mathrm{E}]$

(12) $\neg \mathrm{FX}, \mathrm{w}_{2} \mathrm{t}_{1}[10, \neg \square \mathrm{E}]$

(13) $\forall \mathrm{x}(\mathrm{Ix} \leftrightarrow \square \forall \mathrm{A}(\mathrm{BxA} \rightarrow \mathrm{A})), \mathrm{w}_{1} \mathrm{t}_{1}[2, \boldsymbol{\square} \mathrm{E}]$

(14) $\mathrm{Ic} \leftrightarrow \square \forall \mathrm{A}(\mathrm{BcA} \rightarrow \mathrm{A}), \mathrm{w}_{1} \mathrm{t}_{1}[13, \forall \mathrm{E}]$

(15) $\quad \forall \forall \mathrm{A}(\mathrm{BcA} \rightarrow \mathrm{A}), \mathrm{w}_{1} \mathrm{t}_{1}[6,14, \leftrightarrow \mathrm{E}]$

(16) $\forall \mathrm{x} \forall \mathrm{A}(\mathrm{BxA} \rightarrow \square \mathrm{BxA}), \mathrm{w}_{1} \mathrm{t}_{1}[3, \mathrm{aE}]$

(17) $\forall \mathrm{A}(\mathrm{BcA} \rightarrow \square \mathrm{BcA}), \mathrm{w}_{1} \mathrm{t}_{1}[16, \forall \mathrm{E}]$

(18) $\mathrm{BcFX} \rightarrow \square \mathrm{BcFX}, \mathrm{w}_{1} \mathrm{t}_{1}[17, \forall \mathrm{E}]$

(19) $\square \mathrm{BcFX}, \mathrm{w}_{1} \mathrm{t}_{1}[9,18, \mathrm{MP}]$

(20) $\mathrm{BcFX}, \mathrm{w}_{2} \mathrm{t}_{1}[11,19, \square \mathrm{E}]$

(21) $\forall \mathrm{A}(\mathrm{BcA} \rightarrow \mathrm{A}), \mathrm{w}_{2} \mathrm{t}_{1}[15, \mathrm{aE}]$

(22) $\mathrm{BcFX} \rightarrow \mathrm{FX}, \mathrm{w}_{2} \mathrm{t}_{1}[21, \forall \mathrm{E}]$

\footnotetext{
${ }^{2}$ For more on modal logic, see, for example, Blackburn, de Rijke and Venema (2001), Chellas (1980), and Hughes and Cresswell (1990). Information about how to combine modal logic and tense logic can be found in, for example, Thomason (2002). For more on the concept of historical necessity (and possibility), see, for example, Chellas (1969), Rönnedal (2012), and Åqvist and Hoepelman (1981). The historical modalities (as well as the absolute modalities) are usually treated as S5 operators in the literature.

${ }^{3}$ For more on doxastic logic, see, for example, Fagin, Halpern, Moses, and Vardi (1995) and Meyer and van der Hoek (1995).
} 
(23) $\mathrm{FX}, \mathrm{w}_{2} \mathrm{t}_{1}[20,22, \mathrm{MP}]$

(24) $\mathrm{FX} \wedge \neg \mathrm{FX}, \mathrm{w}_{2} \mathrm{t}_{1}[12,23, \wedge \mathrm{I}]$

We will call this derivation "the inconsistency argument". Clearly (24) is a contradiction. Hence, $\{(1),(2),(3)\}$ entails a contradiction. It follows that $\{(1),(2),(3)\}$ is inconsistent. Accordingly, at least one sentence in $\{(1),(2),(3)\}$ must be false. This fact justifies the claim that $\{(1),(2),(3)\}$ is an aporia.

\section{Arguments for the Sentences in the Aporia}

I have asserted that the propositions in the aporia of future directed beliefs are intuitively plausible. However, a skeptic might argue that this is not enough to take the puzzle seriously. To show that we should take it seriously, we must have some independent reasons for the sentences in $\{(1),(2),(3)\}$. We cannot rely simply on our intuitions. Therefore, I will consider some arguments for (1) and (3), which seem more problematic than (2). Since (2) is just a definition of the concept of infallibility, I will not consider any arguments for this proposition in this section. However, I will say something more about it in Section 3.

\subsection{Arguments for (1): It Is Possible That There Is Someone Who Is Infallible That Believes Something About the Future That Is Not Historically Settled}

Is it possible that there is someone who is infallible that believes something about the future that is not historically settled? The following argument, which I will call the "conceivability argument," suggests that proposition (1) is true/valid.

\subsection{The Conceivability Argument}

(i) It is conceivable that there is an infallible individual who believes that something will be the case even though it is not historically settled that it will be the case.

Hence, (1) It is possible that there is someone who is infallible that believes something about the future that is not historically settled.

If conceivability implies possibility, then the conceivability argument is valid. However, it is not obvious that this is the case. Nevertheless, it seems reasonable to say that if something is conceivable, then, at least, we have a prima facie reason to believe that it is possible. So the conceivability argument seems to give some support to (1). ${ }^{4}$ The following scenario suggests that (i) is true. Imagine an infallible individual called "Sophia." Suppose that Sophia believes that Germany will win the next World Cup in football and that it is not historically settled that Germany will win the next World Cup in football. Then there is a proposition A, such that Sophia believes that it will be the case that A even though it is not historically settled that A. Furthermore, since Sophia is infallible, there is an individual $\mathrm{x}$ such that $\mathrm{x}$ is infallible and there is a proposition A such that $\mathrm{x}$ believes that it will be the case that A even though it is not

\footnotetext{
${ }^{4}$ For more on the idea that conceivability implies possibility and for some arguments for and against this thesis, see, for example, Szabó Gendler and Hawthorne (2002).
} 
historically settled that it will be the case that A. This scenario is conceivable (clearly it is logically possible). Hence, (i) is true. And since (i) is true, we have at least some reason to accept (1).

\subsection{Arguments for (3): It Is Necessary That All Our Beliefs Are Historically Settled}

Is it true that it is necessary that all our beliefs are historically settled? I will first consider an "intuitive" argument for proposition (3) and then I will consider a semantic argument.

\subsection{The Intuitive Argument}

If (3) is not true, it seems that what someone believes might depend on what will turn out to be the case in the future, which seems unreasonable. Suppose, for example, that it is not now historically settled that Germany will win the next World Cup in football. It is (now) historically possible that Germany will win and it is (now) historically possible that it is not the case that Germany will win. Suppose, furthermore, that Sophia is infallible. Then, if (3) is not true, we can say that it is not now historically settled whether Sophia believes that Germany will win or not. If Germany will win, then it will be true (then, when they have won) that it was the case (now) that Sophia believed that Germany would win; and if Germany will not win, then it will be true (then, when it is settled that they did not win) that it was the case (now) that Sophia did not believe that Germany would win. However, at this moment in time, whether Sophia believes that Germany will win or not is not historically settled. There is simply no way now to tell for sure whether Sophia believes that Germany will win or not. This seems to be a strange position. Is it not, at least sometimes, possible for us to know for sure what we believe about (historically) contingent affairs in the future? Examples such as this clearly suggest that (3) is true.

However, this is not the only possible argument for (3). There are actually several possible semantic arguments for this proposition. I will now mention one such argument, which I will call "the semantic argument."

\subsection{The Semantic Argument}

Consider the following condition:

(C) If the possible world $\mathrm{w}^{\prime}$ is historically accessible from the possible world $\mathrm{w}$ at the time $\mathrm{t}$ and the possible world $\mathrm{w}^{\prime \prime}$ is doxastically accessible from $\mathrm{w}^{\prime}$ at $\mathrm{t}$ for the individual $\mathrm{c}$, then $\mathrm{w}^{\prime \prime}$ is doxastically accessible from $\mathrm{w}$ at $\mathrm{t}$ for $\mathrm{c}$.

Assume that (C) holds. Then we can show that (3) is valid. Here is the proof. Suppose that $\square \forall \mathrm{x} \forall \mathrm{A}(\mathrm{BxA} \rightarrow \square \mathrm{BxA})$ is not true in some possible world $\mathrm{w}_{0}$ at some moment in time $t_{0}$. Then there is a possible world $w_{1}$ and a moment of time $t_{1}$, such that $\forall \mathrm{x} \forall \mathrm{A}(\mathrm{BxA} \rightarrow \square \mathrm{BxA})$ is false in $\mathrm{w}_{1}$ at $\mathrm{t}_{1}$. Hence, $\forall \mathrm{A}(\mathrm{BcA} \rightarrow \square \mathrm{BcA})$ is false in $\mathrm{w}_{1}$ at $\mathrm{t}_{1}$ (for some arbitrary individual c). Accordingly, $\mathrm{BcX} \rightarrow \square \mathrm{BcX}$ is false in $\mathrm{w}_{1}$ at $\mathrm{t}_{1}$ (for some arbitrary proposition $\mathrm{X}$ ). Consequently, $\mathrm{BcX}$ is true in $\mathrm{w}_{1}$ at $\mathrm{t}_{1}$, while $\square \mathrm{BcX}$ is false in $w_{1}$ at $t_{1}$. Since $\square B c X$ is false in $w_{1}$ at $t_{1}$, there is a possible world $w_{2}$ that is historically accessible from $\mathrm{w}_{1}$ at $\mathrm{t}_{1}$ in which $\mathrm{BcX}$ is false in $\mathrm{w}_{2}$ at $\mathrm{t}_{1}$. Therefore, there is a possible world $w_{3}$ that is doxastically accessible from $w_{2}$ at $t_{1}$ for $c$ in which $X$ is false in $\mathrm{w}_{3}$ at $\mathrm{t}_{1}$. Since $\mathrm{w}_{2}$ is historically accessible from $\mathrm{w}_{1}$ at $\mathrm{t}_{1}$ and $\mathrm{w}_{3}$ is doxastically 
accessible from $\mathrm{w}_{2}$ at $\mathrm{t}_{1}$ for $\mathrm{c}, \mathrm{w}_{3}$ is doxastically accessible from $\mathrm{w}_{1}$ at $\mathrm{t}_{1}$ for $\mathrm{c}$ (from condition (C)). It follows that $X$ is true in $w_{3}$ at $t_{1}$, for $B c X$ is true in $w_{1}$ at $t_{1}$ and $w_{3}$ is doxastically accessible from $\mathrm{w}_{1}$ at $\mathrm{t}_{1}$ for $\mathrm{c}$. But this is absurd. Hence, our assumption is false. In conclusion, $\square \forall \mathrm{x} \forall \mathrm{A}(\mathrm{BxA} \rightarrow \square \mathrm{BxA})$ is valid.

The arguments in this section clearly establish that we should take the aporia of future directed beliefs seriously. Is there any way to solve this problem? I will now consider some possible solutions.

\section{Some Possible Solutions}

In this section, I will investigate some possible solutions to the aporia of future directed beliefs. I will focus on five attempts. However, first I will mention two other possibilities.

One way to avoid the problem is to accept the idea that there are true contradictions. A so-called dialetheist, which believes that some sentences are both true and false, might accept that it is possible to derive a contradiction from $\{(1),(2),(3)\}$ and yet think that all sentences in this set are true. If there are true contradictions, this might be perfectly acceptable. However, this solution is extreme. Dialetheism is a very controversial thesis, and most dialetheists will probably agree that not every contradiction is genuine (true). So, even a dialetheist might reject the claim that all sentences in $\{(1)$, (2), (3)\} are true. ${ }^{5}$

Another response is to reject some of the inference rules that are used in the inconsistency argument. If some of these rules are not valid, it is perhaps no longer possible to derive a contradiction from $\{(1),(2),(3)\}$. Still, this solution is also quite problematic, since all the rules that are used in the deduction are standard. It is doubtful that this kind of response is the most effective.

If we accept all the rules in the inconsistency argument, then we can derive a contradiction from $\{(1),(2),(3)\}$, and if there are no true contradictions, at least one of the sentences in this set must be false. There are seven possible solutions of this kind to the aporia of future directed beliefs. We can reject all sentences in the set (one possibility), we can reject two sentences in the set and accept one sentence (three possibilities), or we can reject one sentence in the set and accept the rest (three possibilities). I will focus on the last possibility. In particular, I will discuss three solutions that reject (1), one solution that rejects (2), and one solution that rejects (3).

\subsection{Solution 1: Reject (2)}

It is possible to solve the puzzle by rejecting proposition (2). However, this solution seems to be problematic, since (2) is simply a definition of the concept of infallibility. Nevertheless, let me mention one attempt of this kind. If we use the following alternative definition of infallibility, we can block the inconsistency argument and avoid a contradiction:

$\left(2^{\prime}\right) \boldsymbol{\square} \forall \mathrm{x}(\mathrm{Ix} \leftrightarrow \forall \mathrm{A}(\mathrm{BxA} \rightarrow \mathrm{A}))$. It is necessary that for every $\mathrm{x}, \mathrm{x}$ is infallible if and only if everything $\mathrm{x}$ believes is true.

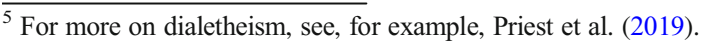


According to this definition, someone can be infallible in some possible world at some moment of time without being infallible in every possible world at every moment in time. Suppose we use (2') and not (2) to define the concept of infallibility. Then step (21) in the inconsistency argument does not go through anymore. But even if we use $(2$ ') to define the concept of infallibility, it seems that we can use (2) to define a new concept that we can call "essential infallibility." And then we can replace "infallible" in (1) and (2) by "essentially infallible" and derive a contradiction again. Therefore, it is doubtful that this is a plausible solution to the aporia. So let us turn to our next solution.

\subsection{Solution 2: Reject (3)}

According to the second solution, we should reject (3). It is not the case that it is necessary that all our beliefs are historically settled. If we reject (3), it is possible that there is someone who believes something even though it is not historically settled that she believes this, that is, the following sentence will be true $\forall \mathrm{x} \exists \mathrm{A}(\mathrm{BxA} \wedge \neg \square \mathrm{BxA})$. This might be true if what we believe can depend on what happens in the future. This idea sounds intuitively implausible. But, on second reflection, perhaps this position is not so unreasonable after all. Some propositions certainly do seem to be historically open. The proposition that Germany will win the next World Cup in football appears to be open. It is not now historically settled whether this proposition is true or not. If Germany will win the World Cup, we can say that the proposition that Germany will win the World Cup was true (now) when they have actually won. However, if Germany will not win the next World Cup, we can say that the proposition that Germany will win the World Cup was not true (now) once it is settled that they did not win. We cannot now know for sure if this proposition is true or not; we have to wait to see who is going to win to "decide" its truth value. Perhaps it is the same with propositions about our beliefs. Perhaps we can believe something even though it is not historically settled that we believe it. If this is true, we can avoid the aporia of future directed beliefs. Of course, if we reject (3), we must also reject (C), since (C) entails (3). Yet, if our beliefs are not historically settled, this seems to be exactly what we should do. ${ }^{6}$

A potential problem with this solution is that there seem to be important and relevant differences between the proposition that Germany will win the next World Cup in football and the proposition that an individual c believes that Germany will win the next World Cup in football. If the future is open, we would expect that the first proposition is not historically settled, since this proposition tells us something about the future. However, the second proposition does not seem to tell us anything about the future. It only tells us something about what someone believes about the future. Hence, we would expect this proposition to be historically settled. Our current beliefs (whether they are about the future or not) do not seem to depend on the future. Since we can derive a contradiction from $\{(1),(2),(3)\}$, we might have to give up these intuitions. But in the meanwhile, let us see if there are any other possible solutions to the aporia.

\footnotetext{
6 This solution is similar to Ockham's solution to a similar problem (see Ockham (1983), especially Question II, Article IV), even though it is not obvious exactly how Ockham should be interpreted.
} 


\subsection{Solution 3: Reject (1) and Assume That It Is Not Possible That the Future Is Open}

According to the third solution, we should reject (1). It is not the case that it is possible that there is someone who is infallible that believes something about the future that is not historically settled. If we reject (1), all an infallible individual's beliefs about the future are historically settled, that is, the following sentence will be true $\forall \forall x(I x \rightarrow \forall A(B x F A \rightarrow \square F A))$.

According to Solution 3, the reason why we should reject (1) is that it is not possible that the future is open. And since the future cannot be open, (1) must be false, for (1) entails that it is possible that the future is open. I will now show that (1) entails that it is possible that the future is open. Let us call this argument "the open future argument."

\subsection{The Open Future Argument}

(1) It is possible that there is someone who is infallible that believes something about the future that is not historically settled.

(2) It is necessary that someone is infallible if and only if it is necessary that everything she believes is true.

Hence, $(\mathrm{O})$ It is possible that the future is open, that is, it is possible that there is a proposition A such that it will be the case that A even though it is not historically settled that it will be the case that $\mathrm{A}$.

(O) can be symbolized in the following way, $\forall \mathrm{A}(\mathrm{FA} \wedge \neg \square \mathrm{FA})$, where all the symbols are interpreted as above. Here is the deduction that shows that $(\mathrm{O})$ follows from (1) and (2):

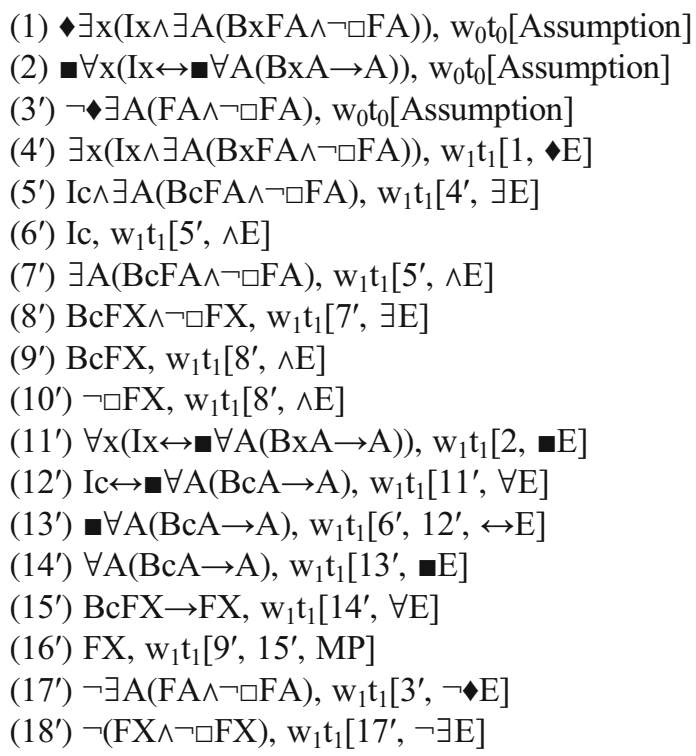

Since $\mathrm{FX} \wedge \neg \square \mathrm{FX}$ is false in $\mathrm{w}_{1}$ at $\mathrm{t}_{1}$, it is either the case that FX is false in $\mathrm{w}_{1}$ at $\mathrm{t}_{1}$ or that $\neg \square \mathrm{FX}$ is false in $\mathrm{w}_{1}$ at $\mathrm{t}_{1}$. Both alternatives lead to a contradiction. This step in the argument follows by propositional logic (PL) and can be symbolized in the following way: 
$\left(19^{\prime}\right) \neg \mathrm{FX}, \mathrm{w}_{1} \mathrm{t}_{1}\left[18^{\prime}, \mathrm{PL}\right]\left(20^{\prime}\right) \neg \neg \square \mathrm{FX}, \mathrm{w}_{1} \mathrm{t}_{1}\left[18^{\prime}, \mathrm{PL}\right]$

(21') $\mathrm{FX} \wedge \neg \mathrm{FX}, \mathrm{w}_{1} \mathrm{t}_{1}\left[16^{\prime}, 19^{\prime}, \mathrm{PL}\right]\left(22^{\prime}\right) \neg \square \mathrm{FX} \wedge \neg \neg \square \mathrm{FX}, \mathrm{w}_{1} \mathrm{t}_{1}\left[10^{\prime}, 20^{\prime}, \mathrm{PL}\right]$

The derivation above establishes that it is not possible that (1) and (2) are true and (O) false. Hence, (O) follows from (1) and (2). So, if we reject the idea that the future can be open, we must also reject (1). And if we reject (1), we can avoid the contradiction that follows from the inconsistency argument.

A problem with this solution is that it clearly seems to be possible that the future is open. In fact, if the dominating interpretations of modern physics are correct, then the future is open. And if the future is open, then it is certainly possible that it is open. ${ }^{7}$ Even if it should turn out that the future is not open, it clearly appears to be possible that not everything that will happen is historically settled. So it seems that we should be reluctant to accept this possible solution.

\subsection{Solution 4: Reject (1) Because It Is Impossible That There Is Someone Who Is Infallible}

Proposition (1) entails that it is possible that there is someone who is infallible. Accordingly, if it is impossible that there is a being of this kind, (1) must be false, and if (1) is false, it does not matter that $\{(1),(2),(3)\}$ entails a contradiction. Hence, we can solve the aporia of future directed beliefs by rejecting (1).

According to Solution 4, we should reject (1) because it is impossible that there is someone who is infallible. But why should we believe this? One could try to show that infallibility entails omniscience and then try to show that it is problematic to assume that it is possible that there is someone who is omniscient. For example, there are several arguments in the literature that suggest that the concept of omniscience is inconsistent with so-called de re and de se beliefs, with human freedom and with the fact that there is no set of all truths. ${ }^{8}$ However, this argument does not succeed, since infallibility does not entail omniscience. Someone can be infallible without being omniscient.

For this solution to work, we should try to show directly that the concept of infallibility is problematic. Perhaps it is possible to establish that the concept of infallibility is inconsistent, and if this concept is inconsistent, it is impossible that there is someone who is infallible. Moreover, if this is impossible, we should reject (1). However, until someone has actually produced such an argument that is convincing, it seems that the conceivability argument (see Section 2 above) gives us a (prima facie) good reason to believe that it is possible that there is someone who is infallible. I conclude that we should be reluctant to accept this solution, at least until someone has actually produced some convincing argument that establishes that the concept of infallibility is inconsistent.

\footnotetext{
${ }^{7}$ For more on various interpretations of modern physics, see, for example, Falkenburg and Weinert (2009), Hodgson (2011), and Salmon (1998, Chapter 2).

${ }^{8}$ For more on the concept of omniscience and some problems with this concept, see, for example, Mavrodes (2010) and Wierenga (2009).
} 


\subsection{Solution 5: Reject (1) and Assume That an Infallible Individual Will Not Have Any Beliefs About Truths About the Future That Are (Historically) "Contingent"}

According to the fifth solution, we should again reject (1). It is not the case that it is possible that there is someone who is infallible that believes something about the future that is not historically settled. However, according to this solution, the reason for rejecting (1) is different. According to Solution 5, we reject (1) because we assume that an infallible individual will not have any beliefs about truths about the future that are not historically settled. An infallible being will only have beliefs about propositions about the future that are historically settled. Suppose it is not historically settled that Germany will win the next World Cup in football. Then an infallible individual will not believe that Germany will win the next World Cup in football. Such a person can still believe many things about the future that are historically settled, for example, that it will be the case that Germany will win or that Germany will not win the next World Cup, that it will be the case that $2+2=4$, and that it will be the case that every bachelor is unmarried. Yet, if it is not historically settled that it will be the case that $A$, then she will not believe that it will be the case that $A$. If (1) is false, then $\square \forall x(I x \rightarrow \forall A(B x F A \rightarrow$ $\square \mathrm{FA})$ ) is true. But this is compatible with the assertion that it is possible that the future is open. It is even compatible with the assertion that the future is open. So this solution is distinct from Solution 3. However, if there are truths about the future that are not historically settled, then an infallible individual will not believe in such truths. ${ }^{9}$

Solution 5 seems to be attractive in many respects. Nevertheless, if we accept it, we have to assume that an infallible individual's beliefs about the future are very limited. She will not believe anything about the future that is not historically settled. If (1) is false, then $\square \forall \mathrm{x}(\mathrm{Ix} \rightarrow \neg \exists \mathrm{A}(\neg \square \mathrm{FA} \wedge \mathrm{BxFA}))$ is true. And this seems counterintuitive.

\section{Conclusion}

In this paper, I have introduced a new aporia, the aporia of future directed beliefs. This puzzle contains three propositions: (1) It is possible that there is someone who is infallible that believes something about the future that is not historically settled, (2) it is necessary that someone is infallible if and only if it is necessary that everything she believes is true, and (3) it is necessary that all our beliefs are historically settled. Every claim in this set is intuitively plausible, and I have mentioned some interesting arguments for or against each of them. However, $\{(1),(2),(3)\}$ entails a contradiction. I have discussed several different possible solutions to this aporia, and I have

\footnotetext{
${ }^{9}$ One way to try to argue for this solution is to reject the principle of bivalence for future contingents. If there were no historically contingent truths about the future, it would be natural to believe that an infallible being would not have any beliefs about the contingent future. The idea that propositions about the contingent future lack truth values is old. According to some interpretations, already Aristotle defended this position (even though this is not the only interpretation of the Greek philosopher). See Aristotle (1963) for more on this. In the twentieth century, Jan Łukasiewicz argued that we need a three-valued logic to deal with similar problems (see the papers in McCall (1967)), a view that seems to have been defended also by A. N. Prior in the 1950s (see Prior (1953)). For more information about the history of this idea and many relevant references, see, for example, Craig (1991) and Øhrstrøm and Hasle (1995). This argument for Solution 5 is interesting, but also problematic, since the principle of bivalence is intuitively very plausible and a part of standard (propositional) logic, and it is possible to accept Solution 5 without rejecting the principle of bivalence.
} 
investigated some arguments for and against these solutions. I have focused on five of the most promising attempts to solve the problem. According to the first solution, we should reject (2), and according to the second, we should reject (3). According to the other three solutions, we should reject (1), but for different reasons. Which solution is the most plausible over all? Which one should we choose? The answer to these questions is not obvious. I am attracted to the fifth attempt, but some of the other solutions also seem interesting to me. The third solution is intuitively very implausible and also seems to go against our current best science, and the first solution seems quite problematic. Nevertheless, the other solutions are not entirely satisfying either. The fact that it is hard to tell which solution we should choose reinforces the claim that the aporia of future directed beliefs really is an aporia. No matter how we choose to solve the aporia, it seems that we have to give up some of our intuitions.

Acknowledgments I would like to thank everyone who has commented on earlier versions of this paper.

Funding Open access funding provided by Stockholm University.

Open Access This article is licensed under a Creative Commons Attribution 4.0 International License, which permits use, sharing, adaptation, distribution and reproduction in any medium or format, as long as you give appropriate credit to the original author(s) and the source, provide a link to the Creative Commons licence, and indicate if changes were made. The images or other third party material in this article are included in the article's Creative Commons licence, unless indicated otherwise in a credit line to the material. If material is not included in the article's Creative Commons licence and your intended use is not permitted by statutory regulation or exceeds the permitted use, you will need to obtain permission directly from the copyright holder. To view a copy of this licence, visit http://creativecommons.org/licenses/by/4.0/.

\section{References}

Åqvist, L. and Hoepelman J. (1981). Some theorems about a "tree" system of deontic tense logic. In New Studies in Deontic Logic: Norms, Actions, and the Foundation of Ethics, ed. Hilpinen, R., D. Reidel publishing company: 187-221.

Aristotle. (1963). Aristotle's "categories" and "De Interpretatione", translated with notes and glossary by J. L. Ackrill. Oxford: Clarendon/Oxford Press.

Blackburn, P., De Rijke, M., \& Venema, Y. (2001). Modal Logic. Cambridge: Cambridge University Press. Chellas, B. F. (1969). The logical form of imperatives. Stanford: Perry Lane Press.

Chellas, B. F. (1980). Modal logic: an introduction. Cambridge: Cambridge University Press.

Craig, W. L. (1988). The problem of divine foreknowledge and future contingents from Aristotle to Suarez. Leiden: E. J. Brill.

Craig, W. L. (1991). Divine foreknowledge and human freedom. Leiden: E. J. Brill.

Fagin, R., Halpern, J. Y., Moses, Y. and Vardi, M. Y. (1995). Reasoning about knowledge. Cambridge, Mass., London, England: The MIT press.

Falkenburg, B. and Weinert, F. (2009). Indeterminism and determinism in quantum mechanics. In Compendium of Quantum Physics, eds. Greenberger, D., Hentschel, K. and Weinert, F., springer: 307311.

Hasker, W. (2011). Divine knowledge and human freedom. In The Oxford Handbook of Free Will, ed. Kane, R., Oxford: Oxford University press: 39-53.

Hodgson, D. (2011). Quantum physics, consciousness, and free will. In The Oxford Handbook of Free Will, ed. Kane, R., Oxford: Oxford University press: 57-83.

Hughes, G. E., \& Cresswell, M. J. (1990). An introduction to modal logic. London: Routledge.

Mavrodes, G. I. (2010). Omniscience. In A companion to philosophy of religion, Second Edition, eds. Taliaferro, C., Draper, P. and Quinn, P. L., Wiley-Blackwell: 251-257. 
McCall, S. (Ed.). (1967). Polish logic 1920-1939. Oxford: Clarendon Press.

Meyer, J.-J. C., \& van der Hoek, W. (1995). Epistemic logic for AI and computer science. Cambridge: Cambridge University Press.

Ockham, W. (1983). Predestination, God's foreknowledge, and future contingents. Translated with an introduction, notes, and appendices by Marilyn McCord Adams and Norman Kretzmann (2nd ed.). Indianapolis: Hackett Publishing.

Øhrstrøm, P., \& Hasle, P. F. V. (1995). Temporal logic: From ancient ideas to artificial intelligence. Dordrecht/Boston/London: Kluwer Academic Publishers.

Priest, G., Berto, F. and Weber, Z. (2019). Dialetheism. In Edward N. Zalta (ed.) Stanford Encyclopedia of Philosophy.

Prior, A. N. (1953). On three-valued logic and future contingents. The Philosophical Quarterly, Vol., 3, 317326.

Rönnedal, D. (2012). Temporal alethic-deontic logic and semantic tableaux. Journal of Applied Logic, 10, 219-237.

Salmon, W. C. (1998). Causality and explanation. Oxford: Oxford University Press.

Szabó Gendler, T., \& Hawthorne, J. (2002). Conceivability and possibility. Oxford: Clarendon Press.

Thomason, R. (2002). Combinations of tense and modality. In Handbook of Philosophical Logic, vol. 2, eds. Gabbay, D. and Guenthner, F., Dordrecht: Reidel: 135-165 (2nd edition 7, 2002: 205-234).

Wierenga, E. R. (2009). Omniscience. In The Oxford Handbook of Philosophical Theology, eds. Flint, T. P. and Rea, M. C., Oxford and New York: Oxford University press: 129-144.

Zagzebski, L. (2005). Omniscience, time, and freedom. In The Blackwell Guide to the Philosophy of Religion (pp. 3-2), (ed.) Mann, W. E. Hoboken: Blackwell Publishing.

Publisher's Note Springer Nature remains neutral with regard to jurisdictional claims in published maps and institutional affiliations. 